\title{
Foucauldian biopower, homo sacer, and resistance under the Taliban rule in Afghanistan
}

\author{
Tasleem Malik $^{1}$ | Faizullah Jan*2
}

1. Area Study Centre Russia, China, \& Central Asia, University of Peshawar, Peshawar, Pakistan.

2. Department of Journalism \& Mass Communication, University of Peshawar, Peshawar, Pakistan.

*Corresponding Author Emails: faiz.jan@gmail.com | faiz.jan@uop.edu.pk

\begin{abstract}
This paper uses a qualitative discourse analysis to examine the plight of women under the Taliban rule in Afghanistan (1996-2001) as depicted in Siddiq Barmak's film Osama. Contributing to the debates on the status of women during a regime of terror under the Taliban the paper uses Foucault's biopolitics and Agamben's concept of homo sacer to analyse how women under the Taliban rule were subjected to the technologies of control and regulation and reduced to bare lives stripped of their basic rights. It also critically examines resistance as depicted in the film as a survival strategy for women in the face of a tyrannical regime. The paper argues that though resistance, which is 'a weapon of the weak,' does not promise a change in the destiny, it still reflects the agency of women and a challenge to the hegemonic masculine order. We conclude by arguing that through the 'use of memory', as a mode of resistance the film sends out a message to all the stakeholders to keep in mind the atrocities and violence experienced by the people in Afghanistan, particularly women while striking any political deal with the Taliban.
\end{abstract}

Article History

Received:

March 24, 2021

Last Revised:

May 24, 2021

Accepted:

June 13, 2021

Published:

June 30, 2021

Keywords: Afghanistan, Giorgio Agamben, Mitchel Foucault, Femina Scara, Taliban, homo sacer, resistance, power, agency, biopolitics.

\section{How to Cite:}

Malik, T., \& Jan, F., (2021). Foucauldian biopower, homo sacer, and resistance under the Taliban rule in Afghanistan. Liberal Arts and Social Sciences International Journal (LASSIJ), 5(1), 582-596. https://doi.org/10.47264/idea.lassij/5.1.38

\section{Publisher's Note:}

IDEA PUBLISHERS (IDEA Journals Group) stands neutral with regard to the jurisdictional claims in the published maps and the institutional affiliations.

Copyright: (C) 2021 The Author(s), published by IDEA PUBLISHERS (IDEA Journals Group). This is an Open Access article published under the Creative Commons Attribution-NonCommercial 4.0 International License (http://creativecommons.org/licenses/by-nc/4.0/) 


\section{Introduction}

At every historical juncture in Afghanistan, mayhem resulting from socio-political and economic turbulence has affected women the most. The fate of women, who are "doomed to live dreadful lives", is decided by the ethno-cultural values mingled with the varied interpretations of Islamic beliefs (Jalal \& Silva, 2016). In the predominantly tribal Afghan society, tribal laws often take precedence over Islamic and constitutional laws in deciding gender roles. Women are generally considered as receptacles of honor, and are expected to stay in the domestic sphere, observe Pardah and are voiceless (Ghosh, 2003). Still, women were not always as oppressed by the conservative tribal values and orthodox fundamentalist beliefs as they were under the mujahedeen and the Taliban. Women characters from history such as 19-year-old Malalai during the battle of Maiwand, the second Anglo-Afghan war, took part in shaping the course of Afghan history and encouraging the men on the battlefield.

Afghanistan has a history of progressive efforts towards providing the rights of citizens and developing the basis for an egalitarian society. Throughout the Twentieth Century, the central leadership in Afghanistan embarked upon several modernization projects, funded and influenced by the outside powers and modelled on the similar projects in Iran and Turkey. The birth of modern Afghanistan is attributed to Amir Abdur Rehman Khan (1880-1891) as significant changes were brought in women status during his reign; women were given the right to inheritance, the right to divorce and the tribal custom of widows marrying the brother of their deceased husband was abolished. His wife Bobo Jan was the first Afghan queen to appear in public in Western clothes and without a veil. After his death, his son Amir Habibullah Khan continued with the progressive agenda of his father (Jalal \& Silva, 2016; Ghosh, 2003; Magnus \& Naby, 1998).

In 1919, Aman Ullah Khan, the new ruler of Afghanistan, continued with the modernization projects under the influence of his wife Soraya Tarzi and her father Mahmoud Tarzi. At a public function, Soraya Tarzi tore off her veil and the wives of other officials present at the meeting followed suit. Aman Ullah discouraged the practice of polygamy and keeping women behind veils and closed doors (Jalal \& Silva, 2016). Many organizations run by females worked for protecting women against oppression, injustice and discrimination. Queen Soraya started a woman magazine Ershad e Niswan. However, things changed when conservative men (particularly mullahs) in the late 1920s came in full protest against what they called Westernization and modernization and a challenge to their familial and tribal authority (Ghosh, 2003; Jalal \& Silva, 2016). Resistance forms the traditionalists became strongest when women were given a right in 1921 to choose their own partner, and when in 1924, the bride price was forbidden and the marriageable age for girls was raised to eighteen years. As the pressure mounted, he and the rulers after him gave in to the whims and demands of tribal leaders and therefore in 1930s and 1940s women in Afghanistan saw a cautious introduction of rights (Ghosh, 2003).

In the post-monarchy period, by the mid twentieth century with massive foreign assistance Afghanistan underwent modernization. To help Afghanistan achieve its developmental goals it was perceived for women to be active participants in economic activity (Ghosh, 2003). Women were seen in the public sphere and that too without veil. In 1950s and 1960s, they entered the workforce as doctors, nurses, teachers and politicians. In 1964, they were entitled to the right to vote. During the presidency of Daud Khan (1970-1978) progressive and liberal reforms continued and women enjoyed personal freedoms and many rights. It was in 1977, 
Meena, a female activist laid the foundations of Revolutionary Association of the Women of Afghanistan (RAWA). Women from RAWA platform criticized the tribal and conservative elements and the war crimes committed by the mujahedeen. The People's Democratic Party of Afghanistan (PDPA), with the backing of the Soviet Union introduced large-scale social reforms in Afghanistan: including the liberal reforms and more rights for women. There was little tolerance for conservative elements in the regime who were confronted with brute state power. The mishandling of tribal riwaj and religious elements led to resentment, which was crushed, by the PDPA killing scores of opponents (Jalal \& Silva, 2016). Reforms by the PDPA and the Soviet-backed government led to resentment, killing of reformers by the opponents of regime and of women donning Westerns clothes (Jalal \& Silva, 2016).

In 1992, the mujahedeen took over Kabul and set up an Islamic state. Now the authority rested with those who considered women as weaker and subordinate to men. During Mujahedeen's rule (1992-1996), there were scores of stories told daily about the unprecedented barbarism, killings, amputations, rapes, forced marriages and other forms of violence. To avoid forced marriages and rape, women even committed suicides (Ghosh, 2003). Then came the Taliban on the political stage of Afghanistan. They took measures to regulate every aspect of life. Playing music and flying kites were prohibited. Men were asked to grow full-length beards. A department of Amar Bil Maroof Wa Nahi Anil-Munkar (the Promotion of Virtue and Prevention of Vice) was set up to monitor and control women's behavior (Ghosh, 2003). The regime took it as its responsibility to protect the dignity of the women and preserving the traditional gender norms. Strict restrictions were imposed on women. They could not appear in the public sphere without a mehram ${ }^{l}$ accompanying them. The women were to wear burqa in the public space. Wearing makeup and high heels were prohibited. They could not attend schools or visit a male doctor. They could not be photographed or filmed. Women were not allowed to appear on balconies or rooftops and all ground floor windows in their houses were to be painted so that women could not be visible to the onlookers in the streets. According to Human Rights Watch (2001) report, those women who were found transgressing the Taliban code were publicly beaten, humiliated and stoned to death.

Things are not much different in post-Taliban Afghanistan as Edwards (2002) mentions the politics in the war-battered country continually revolves around the gendered ideals and power dynamics informed by and initiating the control over women's lives. After the fall of the Taliban, though women could once again work, get education, join politics and under the constitution of 2004 were given equal rights as citizens with the men, the Taliban continued to oppose women liberation and education. The Western intervention in Afghanistan through arms and aid was justified in the name of liberating Afghan women from the oppression of patriarchal structures. As Fluri (2011) rightly remarks that the international intervention capitalizes on the bare life of Afghan women through discursive labelling around lack of capability and need of protection. With US forces leaving Afghanistan, Taliban has re-emerged as main political force in the country. As the memory of the Taliban regime is not yet faded, the new phase in the political history of Afghanistan after the U.S. withdrawal makes the film timeless and relevant. It an attempt to remind and warn at the same time that despite their claims the Taliban with their religious-political ideology will continue with their reign of terror to impose 'Taliban code'. This may have disastrous implications for the people of Afghanistan, particularly women.

There is a growing body of scholarly work on the status of women under the Taliban (e.g., Roshan, 2019; Gregory, 2011; Fluri, 2011; Nguyen, 2011; Das, 2006; Ahmad, 2006). Ahmad 
(2006), for instance, highlights the physical and sexual (in)security of women during the different phases of the war in Afghanistan. She argues that the long-term socio-political and economic consequences of the Soviet invasion and the Afghan civil war have created a systemic sexual violence and oppression of women. During the Taliban regime though there was a decline in the sexual violence against women, still they were oppressed, subjugated, as an underclass and pitiable creatures. Fluri (2011) argues that gender violence and oppression under the Taliban rule made an important narrative for the U.S. intervention in Afghanistan. She discusses how the discourse for the 'just war' in Afghanistan was rooted in the West's colonial and imperial past. Building on the well-worn representations contrasting the American and Middle Eastern men and women, the predominant trope for the war in Afghanistan is "white men rescuing brown women from brown men" (p. 236). Contributing to these debates Osama makes for an evocative and unsettling imagery of how the Taliban in Afghanistan used terror and surveillance as a political strategy to control and govern the citizen, particularly Afghan women. There is already some literature critically discussing the film as one focused on plight of women and their oppression (e.g., Annita, 2016; Everhart, 2006; Cardullo, 2016). This paper contributes to the literature on Osama by discussing the film as visualizing Foucault's concept of the bio political 'state of population' during the Taliban rule in Afghanistan and as to how the regime produced women as homo sacer or famina sacra. This paper also touches upon the resistance of women, which is an unattended dimension of the literature available on the film.

The paper is divided into different sections. After introduction, there is a brief synopsis of the film. The following two sections cover a review of literature on theoretical foundations of the paper and research methodology. In the next two sections, we discuss 'state of populations' in the Taliban-controlled Afghanistan and production of Afghan women as femina sacra. These sections explain that the biopolitical 'state of populations' during the Taliban rule in Afghanistan used terror and surveillance as a political strategy to control and govern the citizen (particularly women) and reduced the women to the status of a homo sacer/femina sacra. The next section examines the resistance exhibited by Afghan women to 'the relations of power' in the Taliban-controlled Afghanistan. Osama depicts cross-dressing, hiding of identity, and deception as resistance strategies adopted by an Afghan girl and a refusal to reduce oneself to a docile subject of power and a 'legible unit' for the state. The film also uses 'memory' as a mode of resistance used by the victims who refuse to be silenced. In the last section, we conclude by arguing that through the 'use of memory', the film sends out a message to the NATO, the U.S., the government in Afghanistan and other stakeholders to keep in mind the violence and oppression experienced by the people of Afghanistan, particularly women while striking any political deal with the Taliban.

\section{Literature review}

Foucault's concept of bio politics explains how power is exercised over the body by regulating and controlling the populace as its main target and having apparatus of security as its mechanism. In The History of Sexuality, Foucault (1978) explains the shift in modern states' role as 'fostering' life as opposed to the ancient right to take life or let live. Power, which takes charge of life, needs continuous regulatory and corrective mechanisms and it affects the distributions around the norm (Rabinow, 1984). This new form of power, the 'bio power' always needs a sovereign exceptionalism to separate the domesticated, norm abiding, docile subjects of power from the outcast, the enemy who has to be excluded from the body politic for the safeguard of society (Edkins \& Pin-Fat, 2005). 
Building on Foucault's theorization of the series of technologies employed by modern States to regulate and control the biological life, Agamben (1998) has presented his concept of homo sacer. Foucault (1978) argues that modern states can barely function without racism which he explains as the States' distinction 'between who must live and who must die'. Extending Foucault's theory and applying it on the Holocaust, the Nazi concentration camps and production of Jewish bare life, Agamben (1998) posits that "production of bio political body is the original activity of sovereign power" separating mere biological existence of man [sic], his bare life from his political life (p. 6). It is this divide, which makes it possible to "protect life and authorize a holocaust" (Agamben, 1998, p. 2). To make his argument, he gives the example of homo sacer from the Roman law, a figure who is excluded and banned from the society by the suspension of law. With the suspension of Roman law, the jus humanum, he lacks protection of civil law and is killable with impunity. However, with the suspension of divine law, he can be killed but not sacrificed. The homo sacer is placed outside of the law, and in this abandonment by the law, is exposed to a constant threat of death.

The Agamben's theorization of homo sacer has been used in thinking about the refugees, stateless people, and migrants (Bauman, 2003; Ek, 2006; Abujidi, 2009). The scholars have also used Agamben's work to advance the feminist politics (Lentin; 2004; 2006; 2011) and expand the available critical tools of the feminist scholarship (Masters, 2009). The work of Lentin (2006, 2004) is significant as it theorizes the women survivors of genocide in Transnistria (Lentin, 2006) and the resistance of Palestinian women in the face of masculinist racial state of Israel (Lentin, 2004; 2011). In discussing the plight of Afghan women as hopeless victims of the Taliban and the colonizing western narratives about their vulnerabilities and disabilities, Masters (2009) uses Lentin's argument to explain the silencing of women, the absence of their narratives in the so-called war on terror and their radical exclusion from politics. She argues that the image of helpless Afghan women as victims of the Taliban warrants their "figural death from the realm of the political, eviscerating the messy complexity of their lives" (p. 44).

Using Agamben's concept of homo sacer, Naseer (2018) explains that women living in the tribal areas along the Pak-Afghan border are victims of riwaj, the tribal custom, and are denied their fundamental rights like right to property, choosing a profession and their life partners. They are considered the property of men and are killed without fear of justice if their decision risks the honour of family or tribe. She argues that like the Roman law which Agamben (1998) mentions in his theorization, riwaj in the tribal areas judges a woman for her certain behaviour that is culturally constructed as an act of dishonour, and hence she is killable like a cursed person. The life of a tribal women resembles homo sacer as she is outside the state law and is reduced to her bare life under the jirga system (traditional judicial system). She is at once included and excluded in the jirga system; included in the tribal law as private property of men, whose ownership changes hands between the father, brother and husband under the tribal customs such as badal/badala/Valwer (bride selling)/Sawara (giving a girl in marriage to the victim family). Naseer (2018) explains how the notion of honour in the tribal riwaj has subjugated women, through 'a strict control of their body, identity, and thinking' to the extent of threatening their very existence.

Contributing to this literature on women bodies as homo sacer and using Agamben's line of argument, we intend to view and analyse Osama and the lives of many Afghan women who have been reduced to the status of their bare bodies. This reduction to bare bodies is still a less discussed dimension of the exercise of power over the female bodies. 


\section{Research methodology}

This paper uses qualitative research analysis method. To evaluate the available data analytical, descriptive and discourse analysis approaches are used. Besides using film as a primary source of data, secondary sources (books, articles, and dissertations) have also been utilized to supplement the argument of the paper. For data collection, the movie was downloaded ${ }^{2}$. For the purpose of discourse analysis and deconstruction of hidden meaning in the dialogues and other non-verbal signs used in the film, we watched the film thrice. The dialogues of the film are in Persian. While watching the movie we wrote down the dialogues in both Persian and English. We watched the film with English subtitles though language was not a barrier for understanding the hidden meanings in the film as both the authors understand and speak Persian well. The dialogues were then analysed critically keeping in view the theoretical framework as we looked for use of surveillance as a mode of governance during the Taliban rule, production of bare life and resistance.

\section{Analysis and discussion}

\subsection{Brief synopsis of Osama movie}

Osama belongs to a special genre of films featured in and about Afghanistan. A significant feature of these films (for instance Kandahar, Samira Makhmalbaf's at Five in the Afternoon, Vahid Mousaian's Golchehreh, and Nelofer Pazira's An act of dishonour) is the political violence and the plight of women in Afghanistan under the Taliban. Written and directed by Siddiq Barmak, an Afghan filmmaker, Osama is the first entirely Afghan film since the rise and fall of the Taliban. The film opens in the middle of a civil-rights protest as Afghan women dressed in blue burqas ${ }^{3}$, a familiar trope of oppressed womanhood in the modern western imageries of gender and equality, call for the right to work and personal freedom. These women, including widows who support their families, are protesting against economic deprivation for being jobless. The Taliban, through a number of decrees removed women from jobs and the public sphere in total disregard to the fact that scores of them were without a male relative because of the decades-long war. Protestors disperse when Taliban soldiers open fire, use water cannons and detain some of them in chicken coops. A widow and her 12-year-old daughter (the protagonist) are on their way home from a hospital where the mother works. They are not part of the protest. They frantically run for their lives before the Taliban notices them. The mother has just lost her job as a nurse as the Taliban closed the hospital. The mother, now jobless and having no male relative, regrets having a girl child. The girl's grandmother comes with an idea of transforming her granddaughter into a boy by cutting her hair and dressing her up as a boy. The grandmother says that men and women are equal "a shaved man under a burqa looks like a woman. A woman with short hair, a hat and pants look like a man". The girl is left with no choice but to save her family. The next day she wakes up metamorphosed as a boy. Besides her mother and grandmother, no one knows the secret except the street urchin Espendi and a shopkeeper who is an old acquaintance of the widow's late husband.

The now androgynous, cross-dressed child works for the shopkeeper. One day a Talib ${ }^{4}$ comes and takes Osama (the name for the unnamed Afghan girl's new assumed identity) to a military training camp along with other boys where she learns to recite the Quran and gets military training. Earlier on, the same Talib had noticed her praying like a female, arousing much suspicion $^{5}$. In the camp, she again finds herself lost between the interchange of her gender role and her identity is always in danger of detection. She even climbs a tree to prove herself as a 
boy. She feared being exposed as a girl when the mullah takes the schoolchildren to the bath and teaches them the correct method of ablution. Though she manages to hide her sex, the mullah is aroused and comments, "This boy looks like a nymph" In the camp Espendi saves her from the boys who suspect her gender and ruthlessly jeer her for her feminine features. It was then that Espendi gives her the name Osama. However, when she menstruates [for the first time?] her real identity is revealed. She is put in jail and is punished with death sentence. To her dismay, she is saved from the punishment when the same mullah takes her into wedlock an equally terrible fate.

\subsection{State of populations in the Taliban controlled Afghanistan}

Discussing the shift in modern state from a 'state of territories' to a 'state of populations,' Foucault (1978) argues that starting in the $17^{\text {th }}$ century, the disciplining of the body and regulation of population constituted the two poles around which the organization of power over life was deployed (Rabinow, 1984). These two poles of power are not antithetical but are linked together by intermediary clusters of relations. While discussing the disciplinary control in the society, Foucault portrays two images of discipline, one the enclosed institutions (family, school, madrassa etc.) and second, dispositif ${ }^{6}$ which makes control mobile, lighter, and more effective. For the discipline in enclosed institutions, Foucault (1978) considers Bentham's panopticon as a machine, an engine and a universally applicable diagram. The utility in the architectural space of panopticon was not in taking revenge but to act in a way of example, manipulating the consciousness of both the imprisoned and citizen. The panopticon signalled the potentiality of abandonment and also the sovereign's reign in potensia through deterrence. In the other image of discipline with mobile control, in what Deleuze (1992) call the 'societies of control', the subject does not move from one enclosed space to another (from family to school etc.) but is subjected to decentralized apparatuses of surveillance. One can comprehend this nomadic control of body as a pre-emptive risk management strategy through biometrics, the digital surveillance and the exceptional measures taken in the post-9/11 world to isolate 'the threatening bodies.' The two images of discipline are clearly visible in the Osama movie. What one observes in Osama fits Agamben's argument:

"It is obvious that we frequently can no longer differentiate between what is private and what is public, and that both sides of the classical opposition appear to be losing their reality. The state of exception consists, not least, in the neutralization of this distinction" (Agamben, 2004, p. 612).

The film depicts that because of surveillance the domestic spaces were not immune from search operations. In one scene when Taliban militants enter a house during a wedding ceremony. In another scene, the mullah is shown putting a lock on the door when he leaves behind his newly wed Osama with his other wives. The chain and the padlock which he offers to his bride symbolizes the regularization of the domestic space through punishment of the non-complying and disobedient. Domestic became the militarized, securitized space, as the survival of the regime was contingent upon annihilation of those who were not willing to comply with the order of the Taliban. Private space was regularized as it was prohibited for women during the Taliban rule to sit in windows and balconies. During the years when the mujahedeen and later the Taliban ruled Afghanistan, they invaded private spaces and searched houses to look for enemies. Thus, a state of exception was created wherein the spatial normalcy and legal structure (ensuring the privacy of home) and cultural tradition of purdah (of home) were suspended within the temporal frame created by the Taliban. During this state (or spatiality) of exception 
the threat was constant, the spatiality was completely invaded and was open to violation without notice. Through the story of Osama, the society of control as depicted in the movie represents the state of limbo, a permanent uncertainty in which the women in Afghanistan under the Taliban lived, never knowing what the next day will bring for them.

An all-seeing eye of the regime and the censorious gaze of the Taliban had penetrated every aspect of life. For example, when it is prayer time a Talib makes sure that shops are closed, and everyone joins congregations in mosques. Taliban militants are shown patrolling the streets and checking passers-by. The widow while returning from the hospital with a man whom she declares her husband is stopped and a Taliban military man chastised her for the 'wanton exposure' of her ankles. In a scene the widow (Osama's mother) rips the family photographs, burns a few papers from her past, and hides the radio to escape the terror if the Taliban notices them. By applying panoptic modalities, power disciplines the body into a docile subject, more susceptible to the hegemonic control. The surveillance creates the atmosphere of terror and fear which Foucault (2008) posits has to be continuous in the society. He argues that governments /states do not let people to be free from fear. The fear is obvious from the facial expression of men (other than the Taliban) and women alike in the movie as they are uncertain what lies for them in the next moment. In a scene, Osama after returning home from the shop tells her mother that the Taliban has noticed her, and they are coming after her. The mother inquires (what did you do?) It shows the expectations of 'normal behaviour' from Osama by the mother as deviance from the expected, subjects them to the killing machine of Taliban rule and which eventually becomes the fate of the young girl.

\subsection{Homo sacer/femina sacra in Osama}

Agamben (1998) argues that the homo sacer, 'the sacred man is the one whom the people judge on the account of a crime... and he who kills him will not be condemned for homicide" (p. 47). Homo sacer, one who can be inscribed in a zone of in distinction, a grey zone; his bare life is situated at the margins of the political order, outside and inside between the $z o \bar{e}$ (a fact of living common to all living beings) and bios (the politically qualified, a living proper).

In Osama, the Afghan women symbolized through the protagonist of the film is depicted as a homo sacer who is reduced to her bare life and can be killed with impunity as honour is attached with the women and they are killed for protecting the sacred law of the Taliban. The film presents the case of female genocide in Afghanistan under the Taliban rule. Women were denied their basic rights, such as right to work and movement. The regime denied the widows a right to exist by denying them access to work and earn their bread. Women were treated like animals under that regime. In the opening scenes Taliban capture some women among the protesters and are shown locking them up in chicken coops. This humiliation and inhuman treatment of women and the devaluation and stripping down of life to bare life relies on a powerful/hegemonic discourse (situated in the interpretation of religion) to determine a life worth living. Such devaluation of life is "at every moment possible in the dissolutio civitatis inaugurated by the state of exception" (Agamben, 1998, p. 64). Lentin (2006) depicts this in the testimonies of women survivors from Transnistria, Ukraine, who narrated being housed in pigsties, stables and cowsheds and forced to travel in cattle carts. In the film it is in response to the fear of reduction to the bare life that Osama uses cross-dressing as a strategy to attain what Agamben calls the 'living proper' and which allows inclusion of the bare life in the public/male sphere of existence. 
Agamben (1998) argues that abandonment of bare life from the political realm is an inclusiveexclusion - in its exclusion from the politically qualified life, the "bare life", the homo sacer is exposed to a more fundamental political relationship with the sovereign who decides whether certain forms of life are unworthy of protection and are thus exposed to death by the sovereign. Inspired by Schmitt's concept that sovereign is the one who decides on exception, Agamben (1998) considers sovereignty as the power to decide on life and its disposability. In fact, it is the zone of indistinction, the inclusive exclusion which Agamben (1998) also calls the 'state of exception' which forms the foundation of sovereign power. Osama's life (and through her the status of Afghan women under the Taliban) is depicted as a life on the margins, on the edge of survival, situated in the zone of indistinction, an inclusive-exclusion; included only by changing the physical appearance, by being banned from men's spaces through burqa and other limitations; included by being related to mehram men in a legal relationship and simultaneously excluded from entitlement to rights such as right to work, to be present in the men's spaces outside home etc. Women are present in the masculine code of the Taliban (imposing restrictions) through their absence. They are rather invoked but are not included.

Osama's presence in the men's space was actually a depiction of women's exclusion. For Agamben (1998), this grey zone, the zone of in distinction inhabited by the bare life, is not completely outside the normal juridical order. It is related to the political space in a relation of ban. To explain the condition of homo sacer and relation of ban, Agamben (1998), gives the example of werewolf - a mythical figure half human and half wolf that neither belongs to the city, because of its animal characteristics, nor to the forest because of its human condition. The ban of the werewolf from the community creates the threshold that holds the bare life and the sovereign inseparable as it was the King in the myth who let the werewolf live in the community through a sovereign decision. Agamben (1998) says that this lupization of man and humanization of wolf represents the inclusive-exclusion and is possible in the state of exception. By cross-dressing the protagonist in the film symbolizes the 'werewolf' which is banned in the domain of proper qualified life under the Taliban rule. She is reduced to her animal life, her zoe. She puts on the human clothes to attain a meaningful existence. The ban here reflects the double meaning, as Agamben (1998) suggests, being prohibited and being free to all. Woman in Afghanistan are prohibited through their invisibility, denying equal status and rights, through the burqa, and are simultaneously free to all; an act of dishonour committed by a woman allows the religious police and the tribal men to decide upon her fate.

Like the werewolf, the Osama has two bodies - a body worth saving (let live) when she is a girl, confined to the space of home, and a body expendable, and which can be killed as a body, which tried to contaminate the male space. In the patriarchal societies where cultural and religious norms set gender roles, women in the men's spaces are considered as 'matter out of place' and excluded from men's spaces to prevent the contamination. The objective/empirical test for this can be seen in Osama when she menstruates and is finally declared a homo sacer. Through menstruation and conforming to her womanhood, the confusion is finally resolved as impurity was seen in the madrassa/camp through the presence of Osama. Menstruation confirmed the impurity thus dissolving the sacredness of the girl. Discussing the fate of the polluted, impure woman, Khan (2009) argues that in the nationalist narratives where the boundaries of the nation states are founded on the notion of puritanism, the impure woman is either reclaimed by the protection of the religion or killed (This is what Osama confirms when she is saved to be wedded to the mullah). Like the proximity between the sovereign and the werewolf in the Bisclavret lay (Agamben, 1998), the Osama is 'given peace' and is let to live with the mullah. 


\subsection{Resistance}

Levi (1988) argues that the state's coercion of its citizens gives rise to the social opposition and resistance against the government, and for Foucault there are no relations of the power without resistance (Rabinow, 1984). Agamben (1998) gives a pessimistic concept of bio politics, where the victim of absolute power (whether the Muselmann or the refugee) has no agency and does not resist power. His homo sacer offers no resistance-individual or in the form of an organized political action. Foucault's theorization of power gives a more nuanced reading of the operation of power. Any major domination is the effect of hegemony and there is always a point of resistance to domination. Resistance in Foucault's work can be linked to the notion of agency as he rejects the notion of subject as a passive recipient of power. It is this Foucauldian reading of resistance and agency of the subject, which explains the theme of resistance in Osama. In Osama, though the Afghan women as a collectivity have been shown exhibiting resistance through a protest when the movie begins and through deception during a wedding ceremony, ${ }^{7}$ the act of resistance, which this article focuses on particularly, is an individual act (by the protagonist).

These everyday acts of the resistance resemble what Scott (1985) has called "weapons of the weak" and include acts of "passive noncompliance, sabotage, subtle evasion, and deception" (p. 31). Not assuming the character of institutionalized politics, the everyday resistance is marked with "implicit disavowal of public and symbolic goals" and focuses on "immediate, de facto gains" (Scott, 1985, p. 33). In the film, cross-dressing is an everyday mode of resistance, a strategy of survival, which leads to a space of ambiguity - a grey zone between the prospective benefits of inclusion and exclusion. As Fluri (2011) argues the bare life becomes a "site of potentiality through transcendental or metaphysical re-birth" (p. 12) attempted by the transference of zoe into bios by cross-dressing. Cross-dressing in Osama is a strategy to attain full and proper (human) life (of men) which is entitled to the right to life and economic development among other basic human rights. The protagonist defies the Taliban code as a docile object of power. She rejects burqa as her identity marker, a device, a technology of power to readily locate her zoe, and chooses an identity which is the norm at the other end of the gender spectrum. She resists the masculine gaze and being caged. Her mother and grandmother have no male relatives and thus they choose to be present in the men's space (i.e., outside their households) to eke out a living.

Though their choice does not show the inversion of men/women binary in the patriarchal structures, it depicts their agency and resistance to those structures. Bare life of Afghan women "... is life on the precipice of potentiality - as a living corpse "in need" of rebirth to bios" (Fluri, 2011, p. 12) through intervention of reason (here the choice to be present in men's space through disguising the real identity). However, the choice made by Osama and many Afghan women is not much different from what Spivak (1998) considers of a sati throwing herself on the pyres of her dead husband, a choice which ultimately exposes her to a fatal destiny; her agency is the agency to kill herself. Osama's choice is an example among many cases in patriarchal societies like Pakistan and Afghanistan. In Afghanistan, during the Mujahedeen rule, a number of women resorted to suicide to escape rape. The narratives of violence accompanying the partition of India in 1947 are abound in women being forced or by choice committing suicides to avoid rape (Khan, 2009; Jan et al., 2021).

The film offers yet another reading of resistance. Osama depicts resistance represented through the act of deception and self-stripping of identity. As identity is the authoritative marker of 
exclusion and inclusion in a state, homo sacer represents the limits on its penetration. States (particularly the modern liberal states) penetrate too deeply into the lives of their citizen in the name of survival and protection of populations. Identification of the body, 'the hazard', in the 'societies of control' (Deleuze, 1992) has become a routine aspect, a 'dispositif' (Foucault, 2008) for the purpose of legibility (Scott, 1988) which subjects the body to varied forms of measurement, classification and surveillance (Rabinow, 1984; Pugliese, 2010). To manage the individualization of the danger and the borders between the normalized, who need protection and the ones to be excluded for maximization of security, the surveillance and monitoring of the populations is done. As a part and parcel of the bio political project, the identification, as 'social sorting' (Lyon, 2003) constructs racialized stereotypes about the 'other' and takes up a necro political (Mbembé, 2019) function where sovereign is concerned much with deciding who is disposable and who is not.

In Osama, the cross-dressing and hiding of identity is an act of resistance by the Afghan girl. It is an attempt to render oneself 'illegible' or refuse to turn into a 'legible unit' (Scott, 1998) for the state's bureaucratic project of control. This identity stripping and the cross-dressing as an example of resistance in the film is also a strategy of survival, an act of self-preservation that counters the annihilation of bare life. The Afghan women are also shown to resist subjugation through deception. The Taliban are deceived in the hospital when the widow saves herself by throwing the burqa over her head and tells the Taliban militant that the man whose father, she is tending to her husband and who later gives her a ride on bicycle to her home. In the scene when women are singing in a neighbourhood wedding ceremony that takes place under the guise of a funeral, they immediately wear burqas when a child informs that the Taliban are coming. The burqa, which is a symbol of masculine authority, becomes the tool of evading power and resisting violence. The daily experience of the Taliban's surveillance and control networks is shown to have enabled the victims to carve out a tactic for infiltrating the control network.

Sadiq Barmak has further portrayed the resistance in the movie through the theme of 'remembering 'and "memory'. The movie opens with the line "I cannot forget but I can forgive". Though Osama is saved from stoning to death, there is an impossibility of forgetting the trauma at the price of survival. She is allowed 'to live' (Foucault, 2008) but actually reduced to a living dead. Siddiq Barmak has used remembrance and memory of the victims as a form of 'resistance' by the victims who refuse to be silenced. Their voices are included as a political strategy as a memory of political violence (Lentin, 2006) in the current 'era of testimonies'. Their narratives of violence experienced are often silenced in the name of shame and 'honour' of family and the wider community. The testimony for their experience is 'non-language'. Lentin (2006) refers to Agamben (1999) "that testimony is non-language, and that our shame prevents us from being able to gaze upon those who reached bottom, whose testimony remains inaccessible" (Agamben (1999) quoted in Lentin, 2006). In the final scenes while the "infidel woman' was being stoned to death for corrupting people, someone in the public asks where is the witness and the reply comes "only God knows". The silenced voice and the body of homo sacer here do not have a witness or testimony and hence is ordered to be killed.

According to Agamben the Muselmann, the homo sacer, cannot bear witness. Following Primo Levi, to make the unspeakability of the Austwitz and possibility of speech through impossibility fathomable, Agamben suggests that the only complete witness is s/he who cannot bear witness - the Muselmann. However, one can see that the wives of mullah at the end are recollecting and remembering the violence of mullah in their personal accounts. The women 
are empowered through their memory, through recalling their own accounts and they refuse to accept the narration of their histories through men, scripted through the collective (patriarchal) memory. The collective memory as Lentin (2006) argues is often "masculinized in the interest of the national or ethical collective" (p. 464). The Afghan women through remembrance and refusing to forget have a distinct memory to form this collective script of history. They themselves recall their victimization. When the mullah brings Osama as her bride to his home, the other wives of mullah recall their suffering at the hand of the Taliban. "May hells swallow up the Taliban, they burned our houses, our land and our gardens". Another wife said: "they arrested and wedded me to this mullah, they ruined my life". The third one says, "Listen dear, we were refugees. When the Taliban captured my brother and killed him, they gave me to this mullah. My life is dark and miserable, he took away my life”. Though they are helpless to make their conditions better, yet through remembrance they narrate their stories, and refuse to be silenced.

\section{Conclusion}

The film Osama is set in the Taliban-controlled Afghanistan. The Taliban imposed a draconian regime regulating every aspect of society, including women's behaviour. The Taliban took it as their responsibility to protect the traditional gender norms and 'Islamic spirit' of society. It is this 'society of control' under the Taliban, which is the focus of Osama. The film's most important contribution is its theoretical implication, a significance that reinforces the relevance of Foucault's concept of bio politics and Agamben's concept of homo sacer to comprehend the complexities of 'relations of power'. The film gives an excellent depiction of how women in Afghanistan were subjected to the technologies of control and regulation, which reduced them to the status of inanimate objects and bare lives, stripped of their basic rights. An all-seeing regime and panoptic gaze under the Taliban are depicted to have penetrated the very intimate aspects of everyday lives. This surveillance creates an atmosphere of fear and terror, which Foucault (2008) states, has to be continuous in a 'society of control'. However, as Foucault posits there are no relations of power without resistance (Rabinow, 1984). Osama depicts this resistance exhibited by Afghan women and refuses to reduce them to the status of a docile object/ subject of power, and to the status of a homo sacer. Through cross-dressing as a strategy for attaining a meaningful existence (a living proper), self-stripping of identity to refuse being a legible unit and the use of memory to refuse being silenced, and the film portrays the resistance and survival strategies adopted by Afghan women that counter the attempts to annihilate their bare lives.

The film and this research paper analysing the technologies of governance under Taliban rule stay relevant to this day, particularly in the current political dynamics in Afghanistan where Taliban have resurfaced as a major player in the country's political landscape. As the international actors and all stakeholders are talking about mainstreaming the so-called moderate Taliban into the politics and national life of Afghanistan, women in Afghanistan are excluded from the peace-brokering process, their experiences and concerns with the Taliban are being ignored. For those who are concerned about democracy, and human rights (the values which they fought for in Afghanistan and hence term their intervention as a 'just war'), this film is a re-enactment of the past in the present, a flash back of the memory. In this context, the opening lines 'I can forgive but I can't forget' are pertinent as the current regime in Afghanistan, the NATO and other stakeholders must make peace with the Taliban but not at the cost of forgetting the past experience. Concessions should be given to the Taliban but not without an equivalent promise to keep peace and giving up violent politics. 
There must be a realization that peace, democracy and gender equality are interlinked and are the foundations of human-cantered societies (Jalal \& Silva, 2016). A society with a belief in the status, entitlements and right claims divided on the bases of religious indoctrination and gendered identities will result in perpetuation of subordination and marginalization of the weak including the poor, women, ethnic and religious minorities. It will further improve the making of culture, religion and gender a justification for war. Any positive and long-lasting change in the current scenario of Afghanistan demands the socio-economic reconstruction connected to wider social changes and a democratic system of governance, which promises the inclusion of women on new terms. In short, women must be entitled to the right to have rights and to the status of a politically qualified life.

\section{Funding acknowledgement}

The author(s) received no financial support for the research, authorship, and/or publication of this article.

\section{Declaration of conflicting interests}

None

\section{References}

Abujidi, N. (2009). The Palestinian states of exception and Agamben. Contemporary Arab Affairs, 2(2), 272-291. https://doi.org/10.1080/17550910902857034

Agamben, G. (2009). What is an apparatus? And other essays. Stanford University.

Agamben, G. (2004). Life, a work of art without an author: The state of exception, the administration of disorder and private life [interview]. German Law Journal, 5(5), 609-614. content/uploads/GLJ_Vol_05_No_05_Raulff.pdf

Agamben, G. (1999). Remnants of Auschwitz: The witness and the archive. Zone Books.

Agamben, G. (1998). Homo sacer: Sovereign power and bare life. Stanford University.

Ahmad, A. (2006). Afghan women: The state of legal rights and security. Policy Perspectives, 3(1), 25-41. https://www.jstor.org/stable/42909150

Annita, A. (2015). Analysis on Islamic women's right and liberation in an Iranian film: Osama. Ultimart: Journal Komunikasi Visual 8(2), 35-42. https://doi.org/10.31937/ultimart.v8i2.466

Bauman, Z. (2003). Wasted lives: Modernity and its outcasts. Polity Press.

Cardullo, R.J. (2016). An Afghan is a woman: Siddiq Barmak's Osama. In R. J. Cardullo (Ed.), Teaching sound film: A reader (pp. 293-303). Sense Publishers.

Das, M. (2006). Taliban's war on women: Live experience of Afghan women in transit on ethnicity and their identity. Asia Research Center Working Paper, No.13. http://eprints.1se.ac.uk/25198/1/ARCWP13MinakishiDasApr2006.pdf

Deleuze, G. (1992). Postscript on the societies of control. October, 59(Winter), 3-7. https://cidadeinseguranca.files.wordpress.com/2012/02/deleuze_control.pdf

Edkins, J., \& Pin-Fat, V. (2005). Through the wire: Relations of power and relations of violence. Millennium, 34(1),

$1-24$. https://doi.org/10.1177\%2F03058298050340010101 
Edwards, D. (2002). Before Taliban: Genealogies of the Afghan Jihad. University of California.

Ek, R. (2006). Giorgio Agamben and the spatialities of the camp: An introduction. Geografiska Annaler. Series B, Human Geography, 88(4), 363-386. https://doi.org/10.1111/j.0435-3684.2006.00228.x

Everhart, M. L. (2006). Osama: Movies as teaching tools. The Geography Teacher, 3(2), 4244. https://doi.org/10.1080/19338341.2006.11089900

Fluri, J. (2011). Capitalizing on bare life: Sovereignty, exception, and gender politics. Antipode, 44(1), 31-50. https://doi.org/ 10.1111/j.1467-8330.2010.00835.x

Foucault, M. (1978). History of sexuality: An introduction. Pantheon Books.

Foucault, M. (2008). The birth of biopolitics: Lectures at the College de France (1978-79). Palgrave Macmillan.

Ghosh, A. H. (2003). A History of women in Afghanistan: Lessons learnt for the future or yesterdays and tomorrow: Women in Afghanistan. Journal of International Women's Studies, 4(3), 1-14. http://vc.bridgew.edu/jiws/vol4/iss3/1

Gregory, T, (2011). Rescuing the women of Afghanistan: Gender, agency and the politics of intelligibility. $\mathrm{PhD}$ dissertation, University of Manchester. https://www.research.manchester.ac.uk/portal/en/theses/rescuing-the-women-ofafghanistan-gender-agency-and-the-politics-of-intelligibility(e4584b58-f8c8-44b2b496-12f89d3a5250).html

Human Rights Watch. (2001). Humanity denied: The systematic violations of women's rights in Afghanistan. http://www.hrw.org/reports/2001/afghan3/afgwrd1001.pdf

Jalal, M., \& Silva, M. (2016). Hanging by a thread: Afghan women rights and security threats. Gyan Publishing

Jan, F., Ashraf, S. I., \& Shah, S. F. A. (2021). Khamosh Pani: Partition trauma, gender violence, and religious extremism in Pakistan. Liberal Arts and Social Sciences International Journal (LASSIJ), 5(1), 16-27. https://doi.org/10.47264/idea.lassij/5.1.2

Khan, S. (2009). Floating on silent waters: Religion, nationalism, and dislocated women in Khamosh Pani. Meridians, 9(2), 130-152. https://doi.org/10.2979/MER.2009.9.2.130

Lentin, R. (2004). No woman's law will rot this state: The Israeli racial state and feminist resistance. Sociological Research Online, 9(3). https://www.socresonline.org.uk/9/3/lentin.html

Lentin, R. (2006). Femina sacra: Gendered memory and political violence. Women's Studies International Forum, 29(5), 463-473. https://doi.org/10.1016/j.wsif.2006.07.004

Lentin, R. (2011). Palestinian women from femina sacra to agents of active resistance. Women's $\begin{array}{llll}\text { Studies International } & \text { Forum, } & 34(3), & 165-170 .\end{array}$ https://doi.org/10.1016/j.wsif.2011.02.001

Levi, M. (1988). Of rule and revenue. University of California.

Lyon, D. (Ed.). (2003). Surveillance as social sorting: Privacy, risk and digital discrimination. Routledge.

Magnus, R., \& Naby, E. (1998). Afghanistan: Mullah, Marx, and Mujahid. Westview.

Masters, C. (2009). Femina Sacra: The 'war on/of terror', women and the feminine, Security Dialogue, 40(1), 29-49. https://doi.org/10.1177\%2F0967010608100846

Mbembe, A. (2019). Necropolitics. Duke University.

Naseer, N. (2018). Tribal women, property and border: An auto ethnographic critique of the riwaj (Tradition) on the Pakistan-Afghanistan borderland. Geopolitics, 24(2), 426443. https://doi.org/10.1080/14650045.2018.1543662 
Nguyen, M.T. (2011). The bio power of beauty: Humanitarian imperialisms and global feminisms in an age of terror. Journal of Women in Culture and Society, 36(2). https://doi.org/10.1086/655914

Pugliese, J. (2010). Biometrics: Bodies, technologies, biopolitics. Routledge.

Rabinow, P. (Ed.) (1984). The Foucault reader. Pantheon Books. https://monoskop.org/images/f/f6/Rabinow_Paul_ed_The_Foucault_Reader_1984.p $\underline{\mathrm{df}}$

Roshan, L.A. (2019). Women, peace and security in Afghanistan. International Journal of Research and Analytical Reviews (IJRAR), 6(1), 228-230. http://ijrar.com/upload_issue/ijrar_issue_20542947.pdf

Scott, J. C. (1985). Weapons of the weak: Everyday forms of peasant resistance. Yale University.

Scott, J. C. (1998). Seeing like a State: How certain schemes to improve the human condition have failed. Yale University.

Spivak, G. C. (1988). Can the Subaltern speak? In Cary Nelson and Lawrence Grossberg (Eds.), Marxism and the interpretation of Culture (pp. 271-313). University of Illinois.

\section{Notes:}

\footnotetext{
${ }^{1}$ Woman's husband and her other male relatives with whom marriage is considered haram

${ }^{5}$ URL of Osama: https://www.youtube.com/watch?v=mpFJJd3ZNPo

${ }^{3}$ A long, loose garment covering the whole body from head to feet, worn in public by women in many Muslim countries

${ }^{4}$ Singular of the noun Taliban

${ }^{5}$ There is a difference of postures between men and women while offering their prayer. For instance, among Sunni Muslims in Qayam (the standing posture) men place their hands below Navel while women place their hands on their chest. Besides there is difference of prayer postures between Shia and Sunni men.

${ }^{6}$ Agamben (2009) defines the apparatus/dispositif as: further expanding the already large class of Foucauldian apparatuses, I shall call an apparatus literally anything that has in some way the capacity to capture, orient, determine, intercept, model, control, or secure the gestures, behaviours, opinions, or discourses of living beings. Not only, therefore, prisons, madhouses, the panopticon, schools, confession, factories, disciplines, judicial measures, and so forth (whose connection with power is in a certain sense evident), but also the pen, writing, literature, philosophy, agriculture, cigarettes, navigation, computers, cellular telephones and — why not-language itself, which is perhaps the most ancient of apparatuses - one in which thousands and thousands of years ago a primate inadvertently let himself be captured, probably without realizing the consequences that he was about to face (p.14).

${ }^{7}$ The wedding ceremony takes place under the guise of a funeral and a child in the attendance informs the women to put on their burkas as the Taliban were coming. Women flipped their burkas on their heads and deceived the Taliban by weeping, swaying, and mourning.
} 